\title{
Editorial
}

\section{Richard Sloan}

This issue contains papers presented at the 2011 Review of Accounting Studies conference entitled "Current Issues in Accounting Research", which was held at the Università Bocconi in November 2011. Professor Sasson Bar-Yosef of Università Bocconi organized a truly memorable conference. We would like to thank him, his staff and colleagues and especially Elisa Santi for their hard work and gracious hospitality. We also thank Università Bocconi and Cambridge Business Publishers for their financial support. Finally, we thank the conference discussants for their insightful comments. Edited versions of their discussions are published alongside the papers in this issue.

Blackrock sponsored this year's prize for the best conference paper. We thank Blackrock for their ongoing support of this prize. This year's best paper (selected by secret ballot from conference attendees) was "Value Investing in Credit Markets" by Maria Correia, Scott Richardson and Irem Tuna. The Morgan Stanley Prize for best discussant was awarded to Annalisa Prencipe for her discussion of "Where do Firms Manage Earnings" by Scott Dryeng, Michelle Hanlon and Edward Maydew. We congratulate our winners and thank our sponsors.

\footnotetext{
R. Sloan $(\bowtie)$

University of California, Berkeley, CA, USA

e-mail: richard_sloan@haas.berkeley.edu
} 